\title{
EFFECT OF PROTEIN AND ENERGY CONCENTRATION IN MILK REPLACERS ON REARING PERFORMANCE OF HEIFER CALVES*
}

\author{
Barbara Niwińska, Krzysztof Bilik \\ Department of Animal Nutrition and Feed Science, National Research Institute of Animal Production, \\ 32-083 Balice n. Kraków, Poland
}

\begin{abstract}
The objective of the study was to analyse the effect of enriching milk replacers with crude protein (CP) and/or gross energy (GE) on rearing performance of Polish Holstein-Friesian heifer calves. The study was a $2 \times 2$ factorial design, with the two factors being CP content (220 and $290 \mathrm{~g}$ ) and GE content ( 21 and 23 MJ) of milk replacer dry matter (DM). Thirty-two heifer calves aged 7 days were assigned to 1 of 4 experimental groups $(n=8)$, in which they received limited milk replacer $(800 \pm 10 \mathrm{~g} \mathrm{DM} \times$ day-1) to 56 days of age and the same concentrate mixture ad libitum to 120 days of age. Feeding programme and nutritive value of concentrate mixture were applied as recommended by IZ PIB-INRA feeding standards (2009). Rearing performance was determined from body weight and body size measures at 7,56 and 120 days of age, and feed and nutrient utilization for weight gain and body size gain during the periods from 7 to 56, 57 to 120 and 7 to 120 days of age. During the liquid feeding period from 7 to 56 days of age, the increase in CP concentration in milk replacers had a statistically significant effect on weight gains, body size $(\mathbf{P} \leq 0.05)$, and utilization of feed DM, CP and GE for weight gain $(P \leq 0.05)$, while the increase in GE concentration improved daily weight gains and utilization of $C P$ for weight gain $(P \leq 0.05)$. The increase in $C P$ concentration and the simultaneous decrease in GE concentration had a beneficial effect on the intake of concentrate mixture (statistical tendency, $\mathbf{P} \leq \mathbf{0 . 1}$ ), but its utilization for weight gain was similar in all the experimental groups. Heifer calves that had received protein-rich milk replacers previously, during the period from 57 to 120 days of age ingested more concentrate mixture per day but were less efficient in nutrient utilization for weight gain (statistical tendency, $P \leq 0.1$ ).
\end{abstract}

Key words: heifer calves, milk replacers, protein, energy, rearing performance

Meeting the nutritional requirements of dairy breed heifer calves during the first weeks of life is essential for their normal biological development, which will ensure optimal milk yields and health later in life (Davis Rincker et al., 2011; Khan et al., 2011). During this period of growth, about $83 \%$ of calves are fed milk replacers (Górka and Kowalski, 2007), which most often contain from 160 to $220 \mathrm{~g}$ crude

\footnotetext{
*This study was conducted as part of NRIAP statutory activity, project no. 2268.1.
} 
protein and about $21 \mathrm{MJ}$ of gross energy per kg of dry matter. In accordance with the recommendations of feeding standards, when restricted liquid feeding is used, this composition of milk replacers meets the nutritional requirements of growing calves while ensuring proper weight gains, body dimensions and intake of solid feeds (NRC, Nutrient Requirements of Dairy Cattle, 2001; IZ PIB-INRA, 2009).

However, recent research results have indicated that actual nutritional requirements of modern dairy cattle, also during early calfhood, are higher than those recommended in feeding standards (Brown et al., 2005). In an effort to ensure optimum weight, body size gains, development of a functional rumen and utilization of solid feeds, a critical analysis was performed on the concentration of crude protein (Hill et al., 2008; Labussiere et al., 2008), energy content (Diaz et al., 2001), and the relationship between protein utilization and availability of energy from feeds given to calves (Bascom et al., 2007). However, research results obtained to date provide no information about optimum composition of milk replacers to ensure the normal biological development of dairy breed heifer calves.

In the present study, it was hypothesized that enrichment of milk replacers with protein and energy would improve weight gains, body dimensions and intake of solid feeds by heifer calves. To validate this hypothesis, we conducted a study to compare rearing performance of heifer calves receiving milk replacers enriched with crude protein and/or gross energy.

\section{Material and methods}

The experiment was carried out in 2009-2010 at the Experimental Station Chorzelów Ltd. of the National Research Institute of Animal Production.

\section{Experimental design}

A growth-feeding trial was conducted with 32 Polish Black-and-White Holstein-Friesian heifer calves during the rearing period from 7 to 120 days of age. The study was a two-factorial design, with factors analysed at two levels $(2 \times 2)$. The experimental factors were crude protein content (220 vs. $\left.290 \mathrm{~g} \times \mathrm{kg}^{-1} \mathrm{DM}\right)$ and gross energy content ( 21 vs. $23 \mathrm{MJ} \times \mathrm{kg}^{-1} \mathrm{DM}$ ) of milk replacers given to experimental animals during the liquid feeding period (from 7 to 56 days of age). At the age of $7( \pm 1.1)$ days, heifer calves were assigned by birth date to 4 dietary treatment groups $(\mathrm{n}=8)$, in which they received limited milk replacer $\left(800 \pm 0 \mathrm{~g} \mathrm{DM} \times\right.$ day $\left.^{-1}\right)$ to 56 days of age containing (per kg of DM) crude protein (CP) and gross energy (GE) in amounts of $220 \mathrm{~g}$ and $21 \mathrm{MJ}$ in group 220/21 (control), $220 \mathrm{~g}$ and $23 \mathrm{MJ}$ in group 220/23, $290 \mathrm{~g}$ and $21 \mathrm{MJ}$ in group 290/21, and $290 \mathrm{~g}$ and $23 \mathrm{MJ}$ in group 290/23, respectively. The composition of milk replacers was calculated based on the proximate chemical analysis of the manufacturer's components I, II and III, and the CP and GE concentrations were considered relative to a reference $\mathrm{CP}$ and GE concentration in the control milk replacer, which were $220 \mathrm{~g}$ and $21 \mathrm{MJ} \times \mathrm{kg}^{-1} \mathrm{DM}$, respectively. Throughout the experiment, heifer calves were fed with concentrate mixtures of the same composition. The composition of the feeds is shown in Table 1. 
Table 1. Composition of experimental feeds $\left(\mathrm{g} \times \mathrm{kg}^{-1} \mathrm{DM}\right)$

\begin{tabular}{|c|c|c|c|c|}
\hline Item & $220 / 21$ & $220 / 23$ & $290 / 21$ & $290 / 23$ \\
\hline \multicolumn{5}{|l|}{ Milk replacers } \\
\hline \multicolumn{5}{|l|}{ manufacturer's components: } \\
\hline I & 381 & 173 & 250 & 46 \\
\hline II & 280 & 482 & 261 & 464 \\
\hline III & 227 & 233 & 377 & 378 \\
\hline yeast & 47 & 47 & 47 & 47 \\
\hline soybean oil & 15 & 15 & 15 & 15 \\
\hline calcium formate & 13 & 13 & 13 & 13 \\
\hline vitamin supplement $^{1}$ & 10 & 10 & 10 & 10 \\
\hline lysine & 7 & 7 & 7 & 7 \\
\hline mineral supplement ${ }^{2}$ & 20 & 20 & 20 & 20 \\
\hline \multicolumn{5}{|l|}{ Concentrate } \\
\hline crushed barley grain & \multicolumn{4}{|c|}{500} \\
\hline crushed wheat grain & \multicolumn{4}{|c|}{247} \\
\hline soybean meal & \multicolumn{4}{|c|}{172} \\
\hline wheat bran & \multicolumn{4}{|c|}{60} \\
\hline mineral and vitamin mixture ${ }^{3}$ & \multicolumn{4}{|c|}{21} \\
\hline
\end{tabular}

${ }^{1}$ Vitamin supplement contained in $1 \mathrm{~kg}$ of DM: vitamins A $(15.58 \mathrm{~g}), \mathrm{D}_{3}(13 \mathrm{mg}), \mathrm{E}(10.38 \mathrm{~g}), \mathrm{B}_{1}(0.42 \mathrm{~g})$, $\mathrm{C}(10.38 \mathrm{~g}), \mathrm{B}_{2}(0.42 \mathrm{~g}), \mathrm{B}_{6}-\mathrm{HCl}(0.21 \mathrm{~g}), \mathrm{B}_{12}(2 \mathrm{mg})$, nicotinic acid $(2.70 \mathrm{~g})$, Ca-pantothenate $(1.04 \mathrm{~g})$, biotin $(21 \mathrm{mg})$, choline chloride $(25.96 \mathrm{~g})$, folic acid $(0.10 \mathrm{~g})$ and iron $(10.38 \mathrm{~g})$.

${ }^{2}$ Mineral supplement (Vetoquinol Biowet Ltd., Gorzów Wielkopolski, Poland) contained in $1 \mathrm{~kg}$ of DM: S $(180 \mathrm{~g})$ and $\mathrm{Cl}(23 \mathrm{~g})$.

${ }^{3}$ Mineral and vitamin mixture (Kälber Mineral, Blattin Polska Ltd., Ozimek, Poland) contained in $1 \mathrm{~kg}$ of DM mineral components: Ca (159 g), P (52 g), Na (77 g), Mg (33 g), Zn (3520 mg), Mn (1388 mg), $\mathrm{Cu}(459 \mathrm{mg})$, Co $(8 \mathrm{mg}), \mathrm{J}(15 \mathrm{mg})$, Se $(15 \mathrm{mg})$ and vitamins: A $(276 \mathrm{mg}), \mathrm{D}_{3}(2 \mathrm{mg}), \mathrm{E}(1531 \mathrm{mg})$, $\mathrm{B}_{1}(280 \mathrm{mg}), \mathrm{B}_{2}(122 \mathrm{mg}), \mathrm{B}_{6}(102 \mathrm{mg}), \mathrm{B}_{12}(1 \mathrm{mg})$, niacin $(638 \mathrm{mg})$, pantothenic acid $(276 \mathrm{mg})$, folic acid $(15 \mathrm{mg})$ and biotin $(2 \mathrm{mg})$.

\section{Nutrition and management of animals}

The amounts of milk replacers given to calves and the nutritive value of control milk replacer and concentrate mixture were in accordance with the requirements recommended by the "Standards of cattle, sheep and goat feeding. The nutritional value of French and Polish feeds for ruminants" (IZ PIB-INRA, 2009). Calves were fed restrictedly with milk replacer liquid: $8 \mathrm{~kg}$ from 7 to 42 days, $6 \mathrm{~kg}$ from 43 to 49 days, and $3 \mathrm{~kg}$ per day from 50 to 56 days of age. The liquid, which was an aqueous solution of the milk replacer at a $7: 1$ weight ratio of water to milk replacer powder, was fed twice daily (08:00 and 13:00 h) from nipple buckets. The replacers were manufactured by Sano - Nowoczesne Żywienie Zwierząt Ltd. from Sękowo (Poland). Throughout the experiment, heifer calves were fed ad libitum with concentrate mixtures. The concentrate mixture was made from the Experimental Station's own feeds. The chemical composition and nutritive value of the experimental feeds are presented in Table 2. Throughout the experiment, animals were housed in individual cages equipped with automatic drinkers and a perforated wooden floor with straw bedding. 
Table 2. Chemical composition and nutritional value of experimental feeds $(n=3)^{1}$

\begin{tabular}{l|r|r|r|r|}
\hline \multirow{2}{*}{ Item } & \multicolumn{5}{c|}{ Milk replacers } & Concentrate \\
& $220 / 21$ & $220 / 23$ & $290 / 21$ & $290 / 23$ \\
mixture
\end{tabular}

${ }^{1}$ Number of analyses.

${ }^{2}$ Calculated according to the formula: lactose content $=$ crude protein - crude fat - ash, expressed in $\mathrm{g} \times \mathrm{kg}^{-1} \mathrm{DM}$ (acc. to NRC, 2001).

${ }^{3}$ Digestible protein in milk replacer $=$ protein digested in the small intestine (acc. to IZ PIB-INRA, 2009).

${ }^{4}$ Protein digested in the small intestine supplied by microbial protein from rumen degraded protein.

${ }^{5}$ Protein digested in the small intestine supplied by microbial protein from rumen fermented organic matter.

${ }^{6}$ Feed unit for milk production (acc. to IZ PIB-INRA, 2009).

\section{Data collection}

Animals were fed individually and the amount of feed intake was recorded daily by weighing feed offered and refused. Feed samples were collected monthly and stored frozen $\left(-20^{\circ} \mathrm{C}\right)$ prior to analysis. Body weight and body dimensions were recorded at the start of the experiment (day 7 of age), following completion of the liquid feeding period (day 56 of age) and at the end of the experiment (day 120 of age). Body weight was calculated as the mean of measurements made on two successive days, prior to morning feeding. Body dimensions were determined from withers height and hip height, which were measured with a measuring stick.

\section{Chemical analyses}

The chemical analysis of feed components and experimental feeds was performed according to standard procedures. DM was determined gravimetrically after drying for $4 \mathrm{~h}$ at $103^{\circ} \mathrm{C}$ (ISO 6496:1999) and ash was determined after combustion for $3 \mathrm{~h}$ at $550^{\circ} \mathrm{C}$ (ISO 5984:2002). CP was determined using the Kjeldahl method (ISO 5983-1:2005). Crude fat was determined gravimetrically after $6 \mathrm{~h}$ extraction with petroleum ether (ISO 6492:1999). The content of neutral detergent fibre 
(NDF), acid detergent fibre (ADF) and acid detergent lignin (ADL) was determined using methods described by Van Soest et al. (1991). Chemical analyses were performed at the Central Laboratory of the National Research Institute of Animal Production.

\section{Calculations}

Lactose, gross energy (GE) and metabolizable energy (ME) contents were calculated using the equations of NRC (2001): lactose $(\mathrm{g} \times \mathrm{kg} 1)=1000-\mathrm{CP}-$ fat - ash and $\mathrm{GE}\left(\mathrm{MJ} \times \mathrm{kg}^{1}\right)=0.057 \mathrm{CP}+0.092$ fat +0.0395 lactose and $\mathrm{ME}\left(\mathrm{MJ} \times \mathrm{kg}^{1}\right)=$ 0.93 GE. Feed unit for milk production (UFL) content was calculated according to IZ PIB-INRA (2009). The content of digestible protein in milk replacer (PDIA) was determined for milk and plant protein components assuming the small intestine digestibility coefficients for non-ruminating calves estimated by Guilloteau et al. (1986). The composition and the nutritive value of the concentrate mixture was calculated according to IZ PIB-INRA (2009), using INRAtion software, ver. 4.05 (INRA, 1988-2004).

The daily gains in body weight and body dimensions, and daily feed and nutrient intake and utilization for weight gain were estimated during the periods from 7 to 56 , 57 to 120 and 7 to 120 days of age.

\section{Statistical analyses}

The statistical differences in the mean values of the analysed parameters were evaluated with Statistica 8 PL software (StatSoft Polska Ltd., Kraków) using a two-way analysis of variance and Duncan's multiple range test. The statistical differences in body weight between the groups of the calves were evaluated assuming initial body weight as a concomitant variable. The effect of protein content (factor 1) and energy content (factor 2) in milk replacers and the interaction of these factors on the values of the analysed parameters were evaluated. Differences between the means were considered as a statistical tendency for the $\mathrm{P} \leq 0.1$ probability level, as significant for the $\mathrm{P} \leq 0.05$ level, and as non-significant for the $\mathrm{P}>0.05$ level.

\section{Results}

The increased concentrations of CP and GE in the milk replacers fed to heifer calves had a beneficial effect on their body weight at 56 days of age (statistical tendency, $\mathrm{P} \leq 0.1)$ and on their daily weight gains $(\mathrm{P} \leq 0.05)$ from 7 to 56 days of age (Table 3). The interaction between increased concentrations of CP and GE in milk replacers had a positive effect on daily weight gains of the calves $(\mathrm{P} \leq 0.05)$ during the liquid feeding period.

During the liquid feeding phase, the mean daily intake of dietary CP and GE depended on their content in milk replacers (Table 4). The lowest intake of concentrate mixture and DM was by calves from the control group (220/21). When only the con- 
centrate mixture was fed (57 to 120 days of age), the increase in $\mathrm{CP}$ concentration in milk replacers had a beneficial effect on the intake of concentrate mixture, DM, CP and GE $(\mathrm{P} \leq 0.1)$, while the increase in GE concentration positively affected $(\mathrm{P} \leq 0.1)$ the intake of concentrate mixture, DM and CP.

Table 3. Body weight and daily weight gains

\begin{tabular}{|c|c|c|c|c|c|c|c|c|c|c|c|c|}
\hline \multirow{3}{*}{ Item } & \multicolumn{4}{|c|}{ Groups } & \multicolumn{4}{|c|}{ Milk replacer content (in DM) } & \multirow{3}{*}{ SEM $^{1}$} & \multicolumn{3}{|c|}{ Effect $^{2}$} \\
\hline & \multirow{2}{*}{$220 / 21$} & \multirow{2}{*}{$220 / 23$} & \multirow{2}{*}{$290 / 21$} & \multirow{2}{*}{$290 / 23$} & \multicolumn{2}{|c|}{$\mathrm{CP}(\mathrm{g})$} & \multicolumn{2}{|c|}{ GE (MJ) } & & \multirow{2}{*}{$\mathrm{CP}$} & \multirow{2}{*}{ GE } & \multirow{2}{*}{$\begin{array}{c}\mathrm{CP} \times \\
\mathrm{GE}\end{array}$} \\
\hline & & & & & 220 & 290 & 21 & 23 & & & & \\
\hline erva- & 8 & 8 & 8 & 8 & 16 & 16 & 16 & 16 & & & & \\
\hline
\end{tabular}

tions $(\mathrm{n})$

Body weight (kg)

Age of calves (days):

7

$42.1 \mathrm{ab}$

$43.3 \mathrm{ab}$

46.0 a 39.8 b

42.7

$42.9 \quad 44.1 \quad 41.5 \quad 1.0$

56

$61.1 \quad 63.3$

67.1

$62.1 \quad 62.2$

$64.6 \quad 64.1$

62.7

$1.1 * \mathrm{t} \quad \mathrm{ns}$

120

108.8

109.6

$111.1 \quad 110$

109.2110 .8

$109.9 \quad 110.1$

1.5 ns ns ns

Average daily weight gains (g)

In the period from - to (days of age):

\begin{tabular}{lllllllllllll}
$7-56$ & $379 \mathrm{~b}$ & $400 \mathrm{ab}$ & $423 \mathrm{ab}$ & $448 \mathrm{a}$ & 389 & 435 & 401 & 424 & 5 & $*$ & $*$ & $*$ \\
$57-120$ & 745 & 725 & 688 & 756 & 735 & 722 & 716 & 740 & 15 & $\mathrm{~ns}$ & $\mathrm{~ns}$ & $\mathrm{~ns}$ \\
$7-120$ & 584 & 582 & 571 & 621 & 583 & 596 & 578 & 601 & 10 & $\mathrm{~ns}$ & $\mathrm{~ns}$ & $\mathrm{~ns}$ \\
\hline
\end{tabular}

${ }^{1}$ The standard error of mean.

${ }^{2}$ The statistical significance marked as: $\mathrm{t}-\mathrm{P} \leq 0.1,{ }^{*}-\mathrm{P} \leq 0.05$ and $\mathrm{ns}-\mathrm{P}>0.1$.

$\mathrm{a}, \mathrm{b}$ - values of means for experimental groups in the same row with the same superscripts are not significantly different $(\mathrm{P}>0.05)$.

The increase in $\mathrm{CP}$ concentration in milk replacers improved utilization of feed $\mathrm{DM}, \mathrm{CP}$ and GE for weight gain $(\mathrm{P} \leq 0.05)$ during the liquid feeding phase, and resulted in a less efficient utilization of concentrate mixture, DM and CP for weight gain $(\mathrm{P} \leq 0.1)$ during the period when only concentrate mixture was fed (Table 5). During the liquid feeding period, the increase in GE concentration in milk replacers resulted in a more efficient utilization of $\mathrm{CP}$ for weight gain $(\mathrm{P} \leq 0.05)$, and in heifer calves receiving milk replacers lower in $\mathrm{CP}$, it lowered the efficiency of GE conversion (interaction, $\mathrm{P} \leq 0.05$ ).

The increase in $\mathrm{CP}$ concentration in milk replacers had a beneficial effect (statistical tendency, $\mathrm{P} \leq 0.1$ ) on hip height and withers height of heifer calves aged 56 and 120 days and on daily gains of these measurements during the liquid feeding period and during the whole experiment (Table 6). The simultaneous increases in CP and GE concentration in milk replacers had a positive effect on body size (statistical tendency, $\mathrm{P} \leq 0.1)$. 


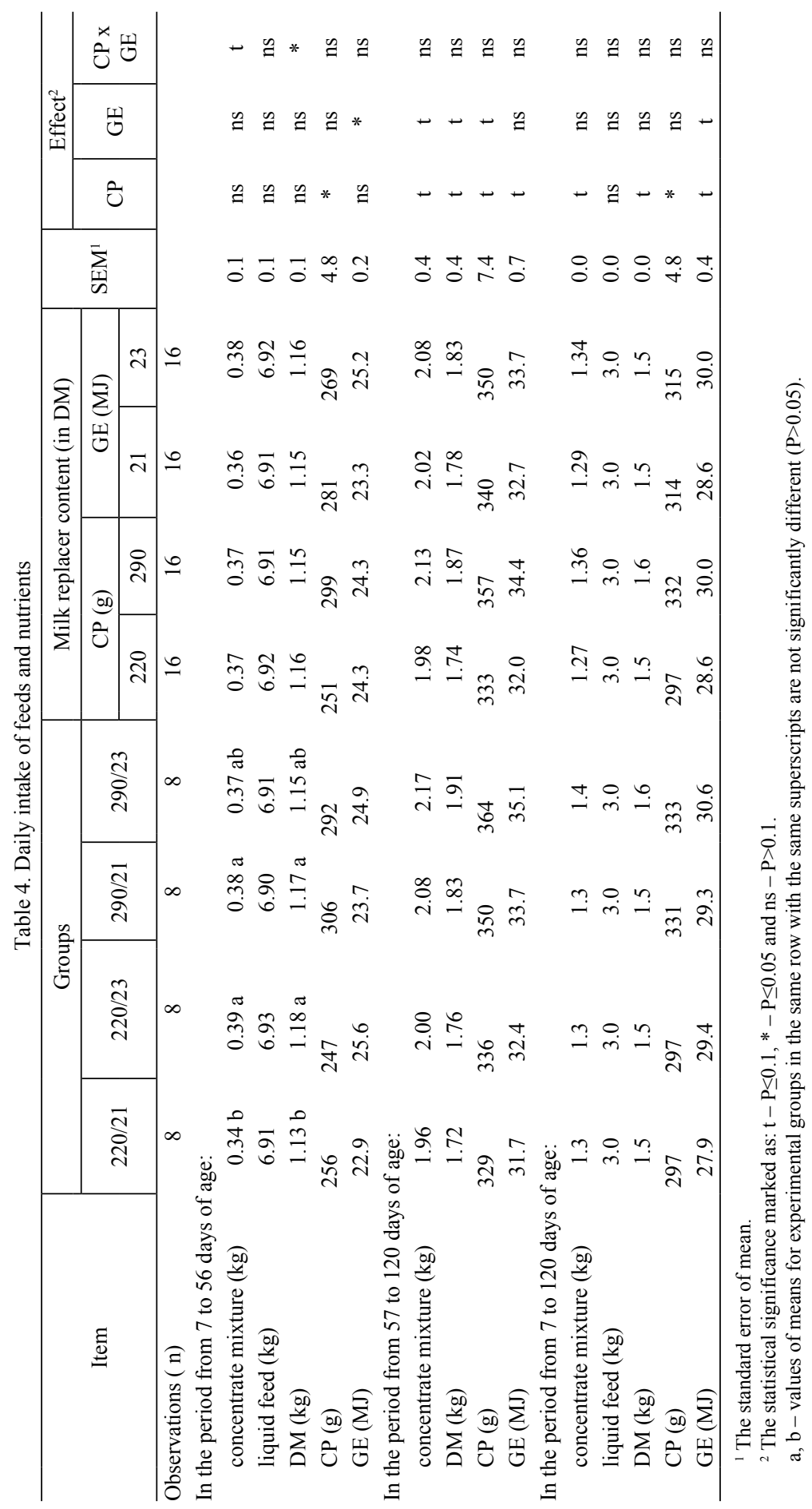




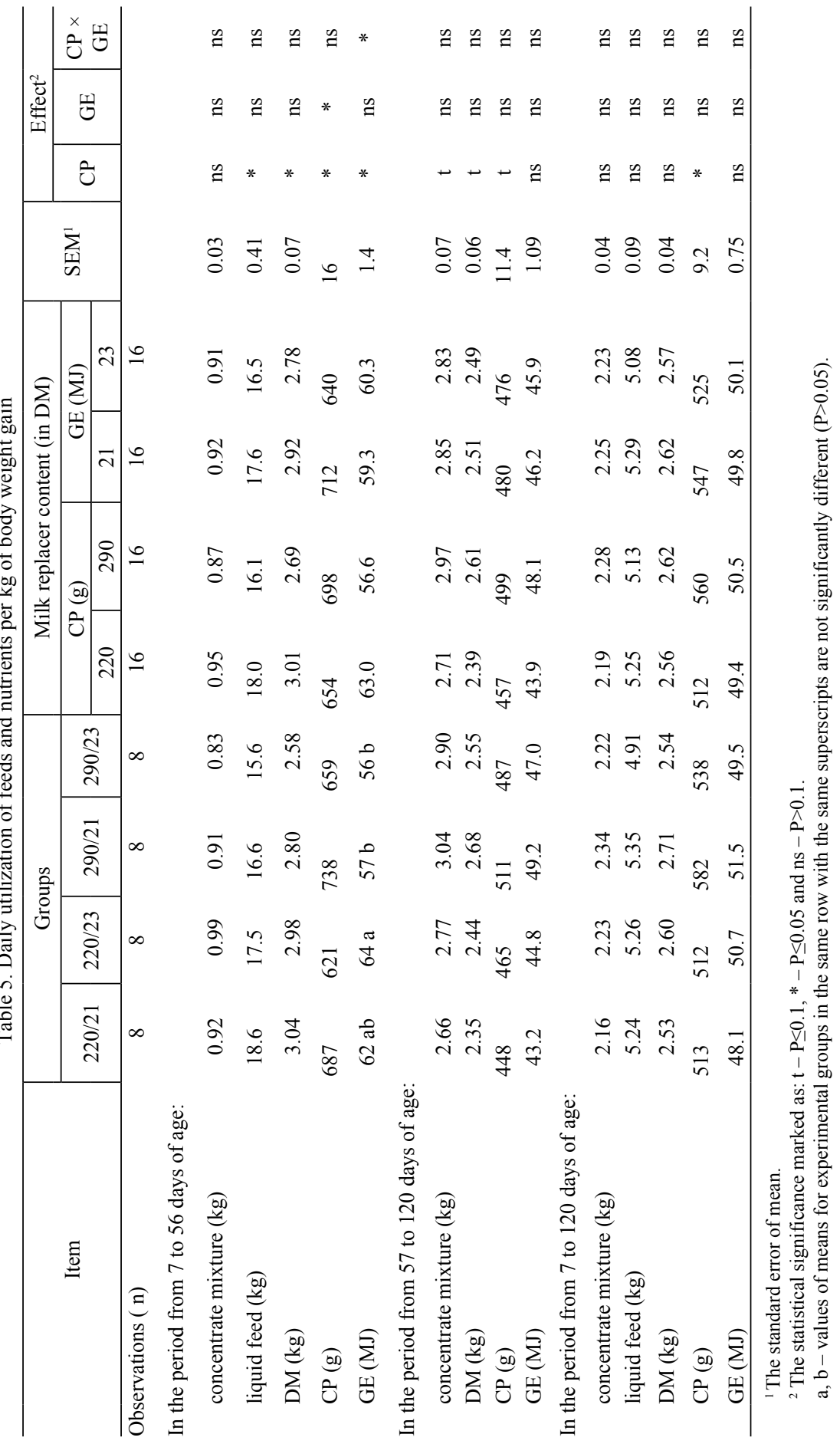




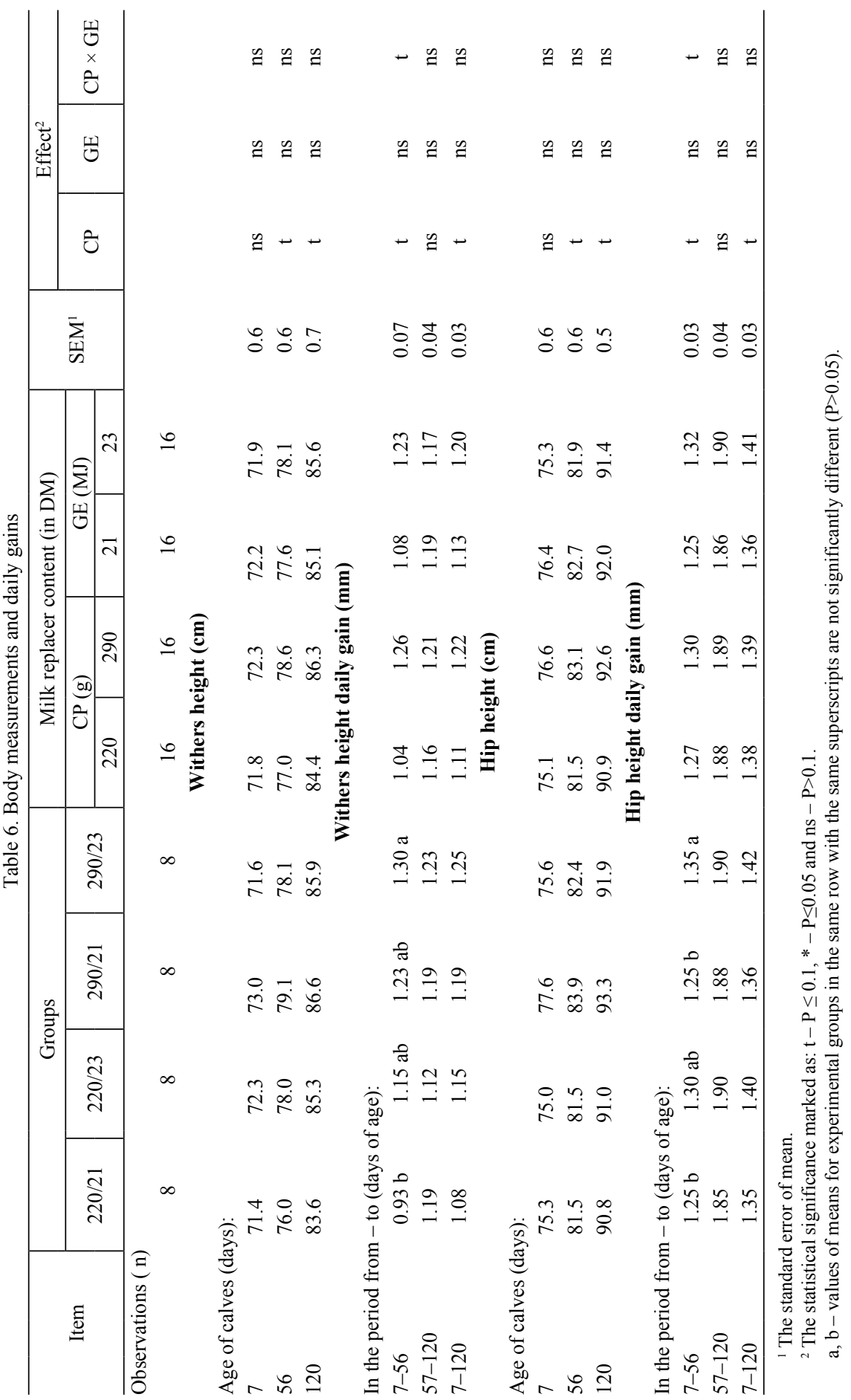




\section{Discussion}

The results obtained indicate that the increased concentration of crude protein, gross energy and both of these nutrients concurrently in milk replacers had an effect on rearing performance of heifer calves during both the liquid feeding period ( 7 to 56 days of age) and the immediately following period of feeding concentrate mixture alone (57 to 120 days of age).

During the liquid feeding period, heifer calves that had an average daily intake of $800( \pm 10) \mathrm{g}$ DM from milk replacers containing $290 \mathrm{~g}$ of CP in DM, achieved higher body weights and body dimensions $(\mathrm{P} \leq 0.1)$, higher daily increases in body weight and body dimensions $(\mathrm{P} \leq 0.1)$, and more efficient utilization of feed DM, CP and $\mathrm{GE}$ for weight gain $(\mathrm{P} \leq 0.05)$ compared to those receiving milk replacers with $220 \mathrm{~g}$ of CP. Our results are in line with the findings of Holstein calf studies published in recent years. Labussiere et al. (2008), who investigated the effect of increased CP concentration (from 190 to $240 \mathrm{~g}$ in $\mathrm{kg} \mathrm{DM}$ ) in isocaloric milk replacers (containing about $20 \mathrm{MJ}$ of GE in $\mathrm{kg} \mathrm{DM}$ ) on rearing performance and protein metabolism of Holstein bulls reared from 5 to 8 weeks of age, found that the increased CP concentration was paralleled by increases in daily weight gain (from 970 to $1090 \mathrm{~g}$ ) and protein content of body weight gain (from 178 to $198 \mathrm{~g}$; $\mathrm{P} \leq 0.01$ ) and a decrease in fat content (from 163 to $90 \mathrm{~g} ; \mathrm{P} \leq 0.01$ ). These correlations were also corroborated by Hill et al. (2008), who studied Holstein heifer calves reared from 4 to 61 days of age. The experiment showed that the increase in CP concentration from 200 to $280 \mathrm{~g}$ was paralleled by improvements in weight gains and body dimensions. The same study also demonstrated that these beneficial changes were paralleled by improvements in protein metabolism, as confirmed by both increased nitrogen retention (from 44 to $65 \%$ ) and higher protein deposition (from 11 to $16 \mathrm{~kg}$ in carcass after slaughter). The results of our study and those reported in the studies cited above concur that with limited liquid feeding, milk replacers containing about 280-290 g CP in DM better meet the protein needs of Holstein calves compared to milk replacers that contain $200 \mathrm{~g} \mathrm{CP}$.

Our results show that rearing performance of heifer calves during the liquid feeding period was also dependent on energy concentration of milk replacers. The increase in energy concentration from 21 to $23 \mathrm{MJ}$ in $\mathrm{kg}$ DM of milk replacers had a beneficial effect on the daily weight gains $(\mathrm{P} \leq 0.05)$ and utilization of diet $\mathrm{CP}$ for weight gain $(\mathrm{P} \leq 0.05)$, but had no effect on the body dimensions of heifer calves $(\mathrm{P}>0.1)$. It seems that the improvement in daily weight gains was due to the high energy availability from the fat added to the milk replacers. Guilloteau et al. (1985) demonstrated that fat utilization by non-ruminating calves is a simple consequence of lipase activity, which according to Sabb et al. (1986) increases as dietary fat content increases from 230 to $290 \mathrm{~g}$. It can be assumed that the increased energy concentration in milk replacers, which had no effect on the body dimensions of the calves, could increase fat deposition in the weight gain. However, this is contradicted by our results and the results of Bascom et al. (2007), who showed an improvement in conversion of feed CP to weight gain. Bascom et al. (2007) observed that an increase in gross energy content of isoproteic milk replacers by 21 or $26 \mathrm{MJ}$ improved conver- 
sion of feed CP to weight gain, which was accompanied by an increase in nitrogen retention from 40 to $56 \%$. The results suggest that when the energy concentration was higher, more nitrogen was used for building the proteins of the growing body. This relationship is confirmed by the findings of Hill et al. (2010), who estimated that milk replacer protein containing about $13 \mathrm{~g} \mathrm{CP}$ per MJ metabolizable is optimally used. In our study, only the milk replacers with higher protein concentrations satisfied this condition.

In addition to optimum weight gains that ensure normal rearing of calves, one problem that remains unsolved is evaluation of the effect of liquid feed composition on the intake and utilization of solid feeds. It has been recognized for many years that during the liquid feeding period, the use of liquid feeds which better meet the nutritional requirements reduces the intake of solid feeds, thus inhibiting the development of a functional rumen and nutrient utilization from solid feeds (Jasper and Weary, 2002; Niwińska and Strzetelski, 2004; Terre et al., 2007). However, these relationships are provided for the level of feeding and not for CP or energy concentration in liquid feeds given restrictedly. In our study, during the liquid feeding period, the increase in CP concentration and the decrease in energy concentration had a beneficial effect on the intake of concentrate mixture (interaction, tendency $\mathrm{P} \leq 0.1$ ), but its conversion to weight gain was similar in all the experimental groups $(\mathrm{P}>0.05)$. It seems that the variation in the utilization of concentrate mixture could result from its low digestibility, which was due to the inadequate production of endogenous amylase, responsible for plant starch digestion, and to the inadequate development of the digestive function of the rumen in calves of that age (Hill et al., 2010). During the period when only solid feed was given, heifer calves that had received protein rich milk replacers ingested more mixture per day $(\mathrm{P} \leq 0.1)$ but were less efficient in nutrient conversion to weight gain $(\mathrm{P} \leq 0.1)$. These relationships suggest that during the liquid feeding period, better nourished animals were more eager to ingest solid feed, but the unstable microbiological processes in the developing rumen prevented the solid feed nutrients from being properly used. Further studies are needed to explain this relationship.

In conclusion, milk replacers containing $220 \mathrm{~g}$ crude protein and about $21 \mathrm{MJ}$ of gross energy per kg of dry matter do not cover requirements for protein and energy of heifer calves during the liquid feeding period. During this growth period, the increase in crude protein concentration to $290 \mathrm{~g}$ in $\mathrm{kg}$ DM of milk replacer improves weight gains and conversion of feed dry matter, crude protein and gross energy to weight gain, while the increase in gross energy concentration to $23 \mathrm{MJ}$ improves the conversion of feed protein.

Enrichment of milk replacers with crude protein has a positive effect on the intake of concentrate mixture but reduces nutrient conversion to weight gain of the calves in the period of concentrate feeding which immediately follows the liquid feeding period. 


\section{References}

B a s c o m S.A., Jame s R.E., M c Gilli ard M.L., V a n A mburgh M. (2007). Influence of dietary fat and protein on body composition of Jersey bull calves. J. Dairy Sci., 90: 5600-5609.

B rown E.G., VandeHaar M.J., Daniels K.M., Liesman J.S., Chapin C.T., Keis le r D.H., W eber Niels en M.S. (2005). Effect of increasing energy and protein intake on body growth and carcass composition of heifer calves. J. Dairy Sci., 88: 585-594.

Davis Rincker L.E., V an de Ha a r M.J., Wolf C.A., Li e s man J.S., Chapin L.T., W e b e r N i e l s e n M.S. (2011). Effect of intensified feeding of heifer calves on growth, pubertal age, calving age, milk yield, and economics. J. Dairy Sci., 94: 3554-3567.

D i a z M.C., V a n A mburgh M.E., S mith J.M., K el s e y J.M., Hutt e n E.L. (2001). Composition of growth of Holstein calves fed milk replacer from birth to 105-kilogram body weight. J. Dairy Sci., 84: 830-842.

Górka P., K ow a lski Z.M. (2007). Milk replacers in the rearing of calves of dairy breeds (in Polish). Med. Weter., 63 (11): 1296-1299.

Guilloteau P., Corring T., Toullec R., Guilhermet R. (1985). Enzyme potentialities of the abomasums and pancreas of the calf. II. Effects of weaning and feeding a liquid supplement to ruminant animals. Reprod. Nutr. Dev., 25: 481-493.

Guilloteau P., Toullec R., Grongnet J.F., Patureau-Mirand P., Prugnaud J., S a u va n t D. (1986). Digestion of milk, fish and soya-bean protein in the preruminant calf: flow of digesta, apparent digestibility at the end of the ileum and amino acid composition of ileal digesta. Br. J. Nutr., 55: 571-592.

Hill S.R., Knowlton K.F., Daniels K.M., James R.E., P e arson R.E., Capuco A.V., A k e r s R.M. (2008). Effects of milk replacer composition on growth, body composition, and nutrient excretion in preweaned Holstein heifers. J. Dairy Sci., 9: 3145-3155.

Hill T.M., B at e man II H.G., Aldrich J.M., Schlotterbeck R.L. (2010). Effect of milk replacer program on digestion of nutrients in dairy calves. J. Dairy Sci., 93: 1105-1115.

J a s p e r J., W e a r y D.M. (2002). Effects of ad libitum milk intake on dairy calves. J. Dairy Sci., 85: 3054-3058.

Khan M.A., W e ary D.M., von Keyserlingk M.A.G. (2011). Invited review: effects of milk ration on solid feed intake, weaning, and performance in dairy heifers. J. Dairy Sci., 94: 1071-1081.

Labussiere E., Dubois S., van Milgen J., Bertrand G., Noblet J. (2008). Effects of dietary crude protein on protein and fat deposition in milk-fed veal calves. J. Dairy Sci., 91: $4741-4754$.

Niwińs ka B., Strzetelski J.A. (2004). Effects of type of liquid feed and feeding frequency on calf performance. J. Anim. Feed Sci., 13, 1: 167-170.

S a b b J.E., Godfrey P.M., B rann on P.M. (1986). Adaptive response of rat pancreatic lipase to dietary fat: Effects of amount and type of fat. J. Nutr., 116: 892-899.

T e r r e M., D e van t M., B a c h A. (2007). Effect of level of milk replacer fed to Holstein calves on performance during the preweaning period and starter digestibility at weaning. Livest. Sci., 110: $82-88$.

Van Soest P.J., Robertson J.B., Lew is B.A. (1991). Methods for dietary fiber, neutral detergent fiber, and nonstarch polysaccharides in relation to animal nutrition. J. Dairy Sci., 74: 3583-3597.

Accepted for printing 13 IV 2012 
BARBARA NIWIŃSKA, KRZYSZTOF BILIK

\section{Wpływ koncentracji bialka i energii w preparatach mlekozastępczych na efektywność wychowu cieliczek}

\section{STRESZCZENIE}

Celem przeprowadzonych badań była analiza wpływu wzbogacenia preparatów mlekozastępczych w białko ogólne (BO) i/lub energię brutto (EB) na efektywność wychowu cieliczek rasy polskiej holsztyńsko-fryzyjskiej. Badania zrealizowano jako 2-czynnikowe $(2 \times 2)$, analizowanymi czynnikami były: zawartość BO (220 i 290 g) i zawartość EB (21 i 23 MJ) w suchej masie (SM) preparatów mlekozastępczych. 32 cieliczki w 7. dniu życia przydzielano do 1 z 4 grup doświadczalnych $(\mathrm{n}=8)$, w których do 56. dnia życia otrzymywały ograniczone dawki doświadczalnych preparatów mlekozastępczych $(800 \pm 10 \mathrm{~g}$ suchej masy $\times$ dzień-1) oraz do 120 . dnia życia do woli tę samą mieszankę treściwą. Program żywieniowy oraz wartość pokarmowa mieszanki były zgodne z zaleceniami norm IZ PIB-INRA (2009). Jako wskaźniki efektywności wychowu przyjęto masę i wymiary ciała w 56. i 120. dniu życia oraz dzienne pobranie i zużycie pasz i składników pokarmowych na przyrost masy ciała w okresach od 7. do 56. od 57. do 120. i od 7. do 120. dnia życia cieliczek.

$\mathrm{W}$ okresie podawania pasz płynnych wzrost koncentracji BO w preparatach mlekozastępczych wpłynął korzystnie na uzyskiwane przyrosty masy i wymiarów ciała $(\mathrm{P} \leq 0,05)$ oraz zużycie $\mathrm{SM}, \mathrm{BO}$ i EB pasz na uzyskanie kg przyrostu masy ciała $(\mathrm{P} \leq 0,05)$, natomiast wzrost koncentracji EB poprawił dzienne przyrosty masy ciała oraz obniżył zużycie $\mathrm{BO}$ na uzyskane przyrosty masy ciała $(\mathrm{P} \leq 0,05)$. Równoczesny wzrost koncentracji BO i obniżenie koncentracji EB wpłynęło korzystnie na pobranie mieszanki treściwej (interakcja statystyczna tendencja $\mathrm{P} \leq 0,1$ ), jednak jej zużycie na przyrosty masy ciała we wszystkich grupach doświadczalnych było podobne.

Cieliczki, które wcześniej otrzymywały preparaty mlekozastępcze bogatsze w białko, w okresie podawania wyłącznie mieszanki treściwej (od 57. do 120. dnia życia) pobierały dziennie nieco więcej mieszanki, lecz równocześnie gorzej wykorzystywały jej składniki pokarmowe na uzyskiwane przyrosty masy ciała (statystyczna tendencja $\mathrm{P} \leq 0,1$ ). 